*avis View/Frint Document Cover Sheet

This document was retrieved from the Boeing ISEARCH System.

Accession \#: D196070170

Document \#: SD-EN-AP-187

Title/Desc:

GUIDELINES FOR MGMT OF NOXIOUS WEEDS AT HANFORD 


\begin{tabular}{|l|l|}
\hline 2. To: (Receiving Organization) & 3. From: Coriginat ing organizat \\
\hline $\begin{array}{l}\text { 5. Proj./Prog./Dept./Div.: } \\
\text { NOX/IPMS/HTS/PSS }\end{array}$ & 6. Cog. Engr.: \\
R. C. Roos/M. B. Malady
\end{tabular}

8. Originator Remarks:

Noxious Weeds, Integrated Pest Management

4. Related EDT No.:

7. Purchase Order No.:

9. Equip./Component No.:

10. System/Bldg./Facility:

11. Receiver Remarks:

12. Major Assm. Dwg. No.:

13. Permit/Permit Application No.:

14. Required Response Date:

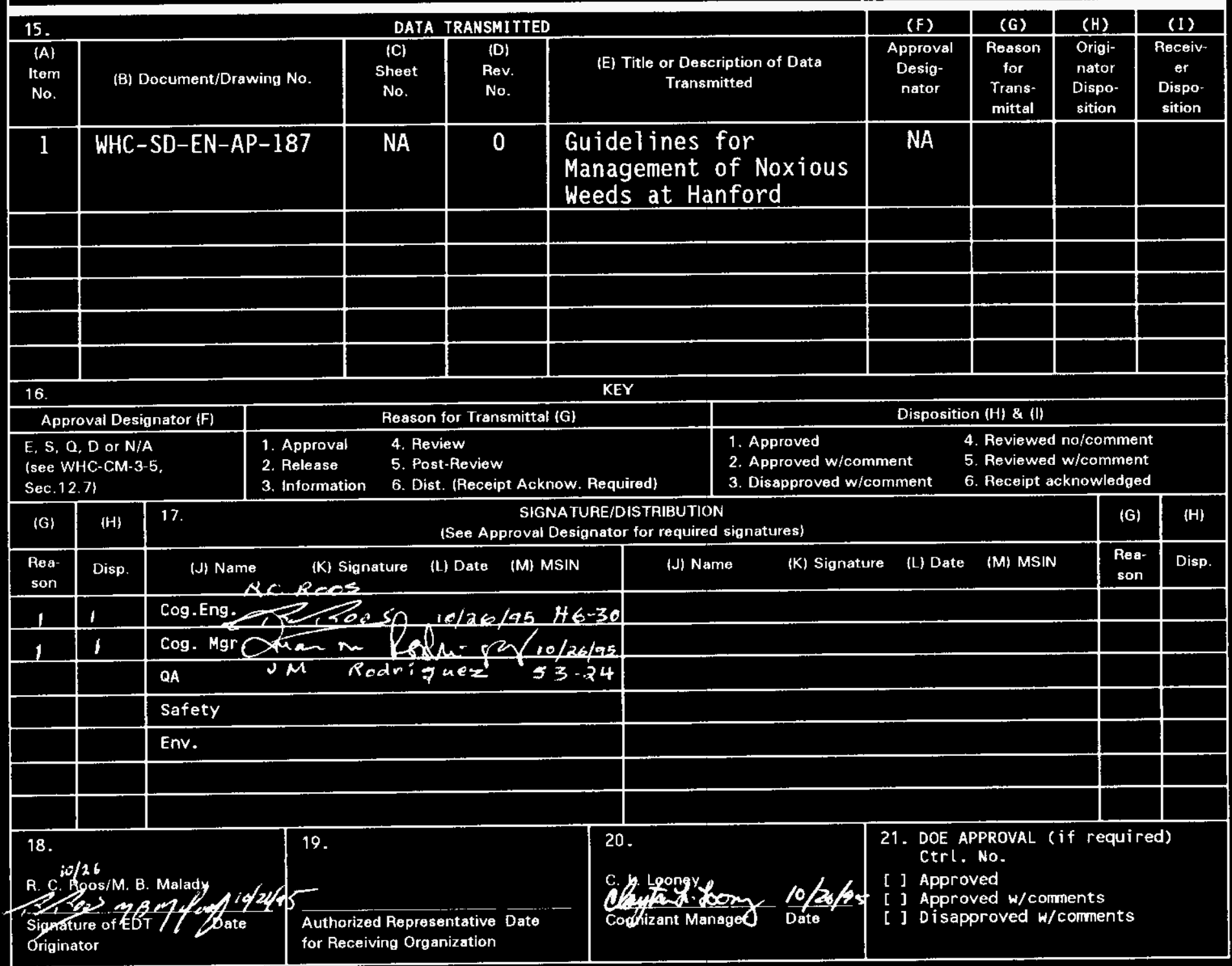

BD-7400-172-2 (04/94) GEF097 


\section{Guidelines for Coordinated Management of Noxious Weeds at the Hanford Site}

Prepared for the U.S. Department of Energy Office of Environmental Restoration and Waste Management

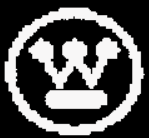
Westinghouse Hanford Company Fichland, Washington

Hanford Operations and Engineering Contractor for the

U.S. Department of Energy under Contract DE-AC06-87RL10930 
LECAL DISCLAMER

This report was prepared as an account of work sponsored by an agency of the United States Government. Neither the United States Government nor any agancy thereof, nor any of their employees, nor any of their contractors, subcontractors or their employees, makes any warranty, express or implied, or assumes any legal liability or responsibility for the

accuracy, completeness, or eny third party's use or the results of such use of any information, apparatus, product, or process disclosed, or represents that its use would not infringe privately owned rights. Reference herein to any specific commercial product, process, or service by trade name, trademark, manufacturer, or otherwise, does not necessarily constitute or imply its endorsement, recommendation, or favoring by the United States Government or any agency thereof or its contractors or subcontractors. The views and opinions of authors expressed herein do not necessarily state or reflect those of the United States Government or any agency thereof.

This report has been reproduced from the best available copy. Available in paper copy and microfiche.

Aveilable to the U.S. Department of Energy and its contractors from

Office of Scientific and Technical Information

P.O. Box 62

Oak Ridge, TN 37831

(615) 576-8401

Available to the public from the U.S. Department of Commerce National Technical Information Service

5285 Port Royal Road

Springfield, VA 22161

(703) 487-4650

Printed in the Unired Stotes of America

DISCLM-1.CHP (1-91) 


\section{RELEASE AUTHORIZATION}

Document Number: WHC-SD-EN-AP-187, Rev. 0

\begin{tabular}{|ll|}
\hline Document Title: & $\begin{array}{l}\text { Guidelines for Management of Noxious Weeds at } \\
\text { Hanford }\end{array}$ \\
\hline Release Date: & $10 / 27 / 95$
\end{tabular}

\section{This document was reviewed following the procedures described in WHC-CM-3-4 and is: APPROVED FOR PUBLIC RELEASE}

WHC Information Release Administration Specialist:

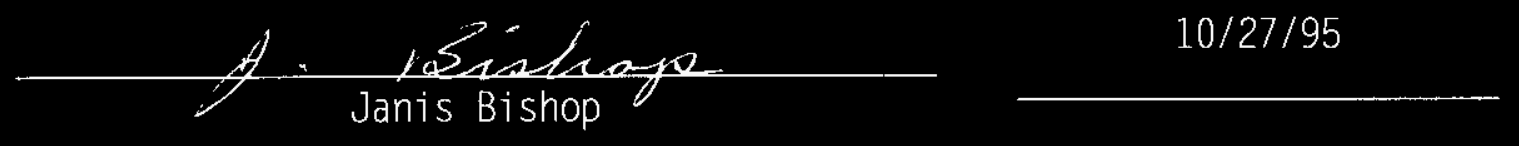

TRADEMARK DISCLAIMER. Reference herein to any specific commercial product, process, or service by trade name, trademark, manufacturer, or otherwise, does not necessarily constitute or imply its endorsement, recommendation, or favoring by the United States Government or any agency thereof or its contractors or subcontractors.

This report has been reproduced from the best available copy. Available in paper copy. Printed in the United States of America. To obtain copies of this report, contact:

Westinghouse Hanford Company - Document Control Services

P. 0. Box 1970, Mailstop H6-08, Richland, WA 99352

Telephone: (509) 372-2420; Fax: (509) 376-4989 


\begin{tabular}{|l|l|l|}
\hline $\begin{array}{l}\text { 2. Title } \\
\text { Guidel ines for Management of Noxious Weeds at } \\
\text { Hanford }\end{array}$ & $\begin{array}{l}\text { 3. Number } \\
\text { WHC-SD-EN-AP-187 }\end{array}$ & $\begin{array}{c}\text { 4. Rev No. } \\
0\end{array}$ \\
\hline $\begin{array}{l}\text { 5. Key Words } \\
\text { Noxious Weed, Weed, Integrated Pest Management }\end{array}$ & $\begin{array}{l}\text { 6. Author } \\
\text { Name: R. C. Roos/M. B. Malady }\end{array}$ \\
\hline & $\begin{array}{l}\text { Signatures } \\
\text { Organization/Charge code 8H113/MDC03 }\end{array}$ \\
\hline
\end{tabular}

\section{Abstract}

Intergrated Pest Management Services is responsible mor management and control of noxious weeds on the Hanford Site. Weed species and populations are prioritized and objectives defined, according to potential site and regional impact. Population controlls are implemented according to priority. An integrated approach is planned for noxious weed control in which several management options are considered and implemented separately or in coordination to best meet management objectives. Noxious weeds are inventories and monitored to provide information for planning and program review.

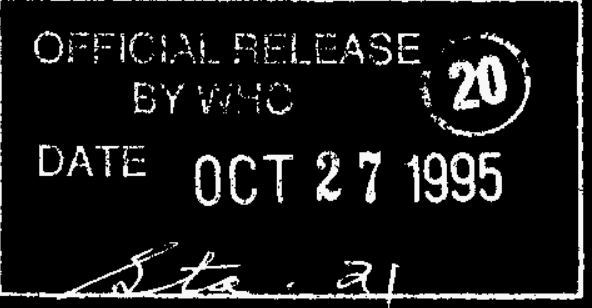




\section{CONTENTS}

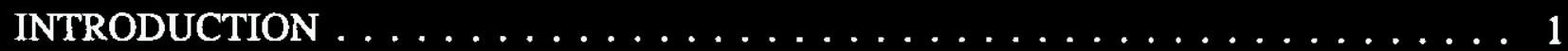

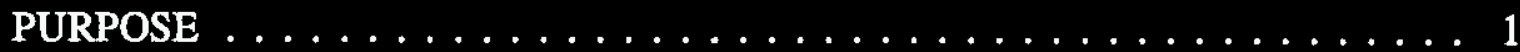

REGULATIONS $\ldots \ldots \ldots \ldots \ldots \ldots \ldots \ldots \ldots \ldots \ldots \ldots$

NOXIOUS WEEDS $\ldots \ldots \ldots \ldots \ldots \ldots \ldots \ldots \ldots \ldots \ldots$

HANFORD SITE MISSION AND WEED MANAGEMENT $\ldots \ldots \ldots \ldots \ldots 2$

INTEGRATED PEST MANAGEMENT ORGANIZATION $\ldots \ldots \ldots \ldots \ldots \ldots \ldots$

WEED MANAGEMENT PROGRAM $\ldots \ldots \ldots \ldots \ldots \ldots \ldots \ldots \ldots$

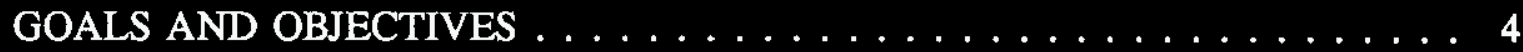

MANAGEMENT STRATEGY $\ldots \ldots \ldots \ldots \ldots \ldots \ldots \ldots$

HANFORD WEED MANAGEMENT UNITS $\ldots \ldots \ldots \ldots \ldots \ldots \ldots \ldots$

AWARENESS EDUCATION AND TRAINING ............... 9

NOXIOUS WEED MANAGEMENT PERSONNEL $\ldots \ldots \ldots \ldots \ldots \ldots$

BIOLOGISTS ON THE HANFORD SITE $\ldots \ldots \ldots \ldots \ldots \ldots \ldots \ldots$

DOE AND WHC MANAGEMENT $\ldots \ldots \ldots \ldots \ldots \ldots \ldots \ldots$

SITE FIELD PERSONNEL $\ldots \ldots \ldots \ldots \ldots \ldots \ldots \ldots \ldots \ldots$

GENERAL SITE PERSONNEL AND PUBLIC $\ldots \ldots \ldots \ldots \ldots \ldots$

PREVENTION AND EARLY DETECTION $\ldots \ldots \ldots \ldots \ldots \ldots \ldots \ldots$

INVENTORY AND MONITORING $\ldots \ldots \ldots \ldots \ldots \ldots \ldots \ldots \ldots \ldots$

INTEGRATED WEED MANAGEMENT . . . . . . . . . . . . . 14 
WHC-SD-EN-AP-187, Rev. 0

This page intentionally left blank. 
WHC-SD-EN-AP-187, Rev. 0

\section{INTRODUCTION}

\section{PURPOSE}

This document outlines the organization, objectives, philosophy of noxious weed control at the Hanford Site. The Noxious Weed Management program has been developed in response to Federal, State, and local laws requiring eradication or control of noxious weeds. In an effort to satisfy agreements made in the Federal Interagency Memorandum of Understanding (MOU 1994) signed by the U.S. Department of Energy (DOE) in 1994, the Noxious Weed Management program at the Hanford Site will serve as a pilot for noxious weed control at other DOE sites around the country.

\section{REGULATIONS}

The DOE, as a steward of land belonging to the people the United States, is obligated by the Federal Noxious Weed Act of 1974 to actively control noxious weeds. Washington Administrative Code (WAC) 16-750 and Revised Code of Washington (RCW) 17.10 require all landowners to control noxious weeds on their property, and impose specific penalties for failure to do so. Other states have similar laws requiring control and management of noxious weeds. In compliance with Federal, State, and local laws, each DOE facility is required to have a noxious weed program.

The DOE is a signatory to the Federal Interagency Memorandum of Understanding agreeing to control noxious weeds on federally managed lands.

\section{NOXIOUS WEEDS}

Any unwanted plant is a weed. According to the RCW, a noxious weed is "any plant which when established is highly destructive, competitive, or difficult to control by cultural or chemical practices" (RCW 17.10.010). Often, plants that form unnoticeable components of their native communities become aggressive invaders in new environments.

Ecological communities have evolved over millennia to a state of dynamic equilibrium. Balance among species is maintained by a number of processes, including competition for resources and the effects of predation. When a species is displaced from the ecosystem in which it evolved, it may no longer be in contact with the species that have evolved with it and kept it in check. A plant species removed from its native ecosystem may begin to propagate and spread without effective natural controls or restrictions. When a weed invades a natural plant community, native plants are already competing for resources (soil, water, nutrients, sunlight, etc.) in the presence of their natural controlling factors (disease, parasites, insects, and herbivores). The displaced plant, or weed, 
removed from its natural controls, often overcomes the native species. Occasionally a single weed species completely replaces the native mixed-species communities.

A plant community composed of a single species is a monoculture. Non-native, or exotic monocultures tend to be biologically sterile. Diversity of food, cover, and other habitat requirements on which native animal communities depend are absent. Consequently, animal species exposed to this situation either die or migrate to other locations. The single plant species remains, occupying space and consuming resources, but contributing little to the overall welfare of the surrounding ecosystem.

\section{HANFORD SITE MISSION AND WEED MANAGEMENT}

The defense and energy-production missions of the approximately $1,450-\mathrm{km}^{2}$ $\left(560-\mathrm{mi}^{2}\right)$ Hanford Site have been replaced with a mission emphasizing environmental cleanup. As environmental cleanup is accomplished, the mission is evolving to one of preserving native ecosystems and wildlife habitat over much of the Site. To accomplish this mission, controlling noxious weeds is imperative. 
WHC-SD-EN-AP-187, Rev. 0

\section{INTEGRATED PEST MANAGEMENT ORGANIZATION}

The Integrated Pest Management (IPM) organization has been given the task of developing and maintaining a program to control and manage noxious weeds on the Hanford Site. The resulting program will serve as a pilot for implementation at other DOE sites around the country. This document outlines the program that IPM is developing for the Hanford Site.

IPM, as the organizational vegetation management contact for the Hanford Site, is working with State and county governments to coordinate weed control for the region. However, the Hanford Site remains its primary focus of responsibility. 


\section{WEED MANAGEMENT PROGRAM}

\section{GOALS AND OBJECTIVES}

The noxious weed management program at the Hanford Site is guided by the following major goals.

\section{Objectives of Control}

The first goal is to meet control objectives for all noxious weed species on site by 2015 (20 years from initiation). At that time, the Hanford Site will not be a source of weeds invading surrounding lands, and infestations of noxious weeds will not affect operations. Weeds will be managed in accordance with the Site's missions, operational needs, and "good neighbor" policy. In some cases, weed species will be eradicated. However, where weed infestation is widespread and seeds are widely transported, eradication only on the Hanford Site may be impractical. In these cases, control efforts will be coordinated regionally.

\section{Objectives of Regional Coordination}

The second goal is to help establish and participate in a Regional Weed Management Program to minimize the return of offsite weeds to the Hanford Site. If the weed-free parcel is surrounded by weed-infested lands, a program designed to keep a parcel weed-free can only succeed through a major, ongoing input of resources. Native vegetation, if well established and undisturbed, can exclude many potential weed invaders. However, weeds from surrounding areas can become established any time native vegetation is disturbed by activities such as grading road shoulders, excavations, off-road vehicle travel, and animal disturbance such as burrowing, heavy grazing, or dust bathing. If a weed-free parcel adjoins weed-infested areas, weeds may be successfully managed only at great expense.

Weeds are controlled most effectively when land managers cooperate regionally. In this way weeds can be controlled in weed management areas bounded by natural barriers to weed transport. A fence between fields cannot prevent weed transport; however, a mountain range with forest vegetation may effectively keep weeds from migrating between areas of desert. Based on the similarity of weed problems, an effective weed management area for the Hanford Site would extend roughly from Spokane, Washington to Hermiston, Oregon and from Walla Walla to Yakima, Washington. Therefore, to be effective, the IPM must coordinate Hanford's objectives and activities with those of neighboring land managers and affected county weed control organizations. 
WHC-SD-EN-AP-187, Rev. 0

MANAGEMENT STRATEGY

The strategy for managing noxious weeds on the Hanford Site is to rank species and populations that require control, then focus resources on infestations with the highest priorities. When a population is identified for control, an integrated program is focused on the population so that plants are killed directly, or the population is weakened and reproduction inhibited. Control measures continue until management objectives are met.

\section{HANFORD WEED MANAGEMENT UNITS}

Weed management objectives vary for different areas across the Site. To facilitate vegetation management, the Site has been divided into the following five weed management units, shown in Figure 1.

Fitzner/Eberhardt Arid Lands Ecology (ALE) Unit

Approximately $110 \mathrm{mi}^{2}$ along the western boundary of the Hanford site make up the Fitzner-Eberhardt Arid Lands Ecology Reserve (ALE). The ALE was set aside in 1971 by interagency cooperative agreement as a Research Natural Area. It is managed to preserve the native sagebrush steppe ecosystem for research. The area comprises the steep north and east slopes of Rattlesnake Mountain and the relatively flat Cold Creek Valley. Vegetation is generally sagebrush/bluebunch, wheatgrass steppe. The area also contains several ephemeral and permanent seeps and springs and is primary range for elk, deer, coyotes, and many other animal and bird species. Major vegetation management considerations are as follows:

- Desire to maintain the native ecosystem

- Coordination with Pacific Northwest Laboratory's research activities.

\section{Saddle Mountain National Wildlife Unit}

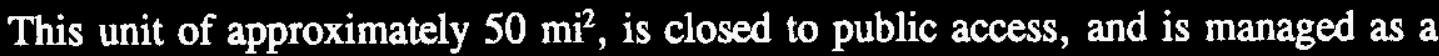
wildlife refuge. It provides critical stopover and wintering habitat for migratory waterfowl and also is important to many other species. Major features include the Columbia River riparian zone and the Saddle Mountain Lakes system fed by waste water and runoff from the Columbia Basin Irrigation Project. The remaining land is abandoned agricultural fields and shrub steppe. The area is leased to the U.S. Fish and Wildlife Service, which is responsible for its management, including weed control. An MOU (MOU 1994) has been 
Figure 1. Hanford Site Weed Management Units.

\section{Hanford Weed Management Units}

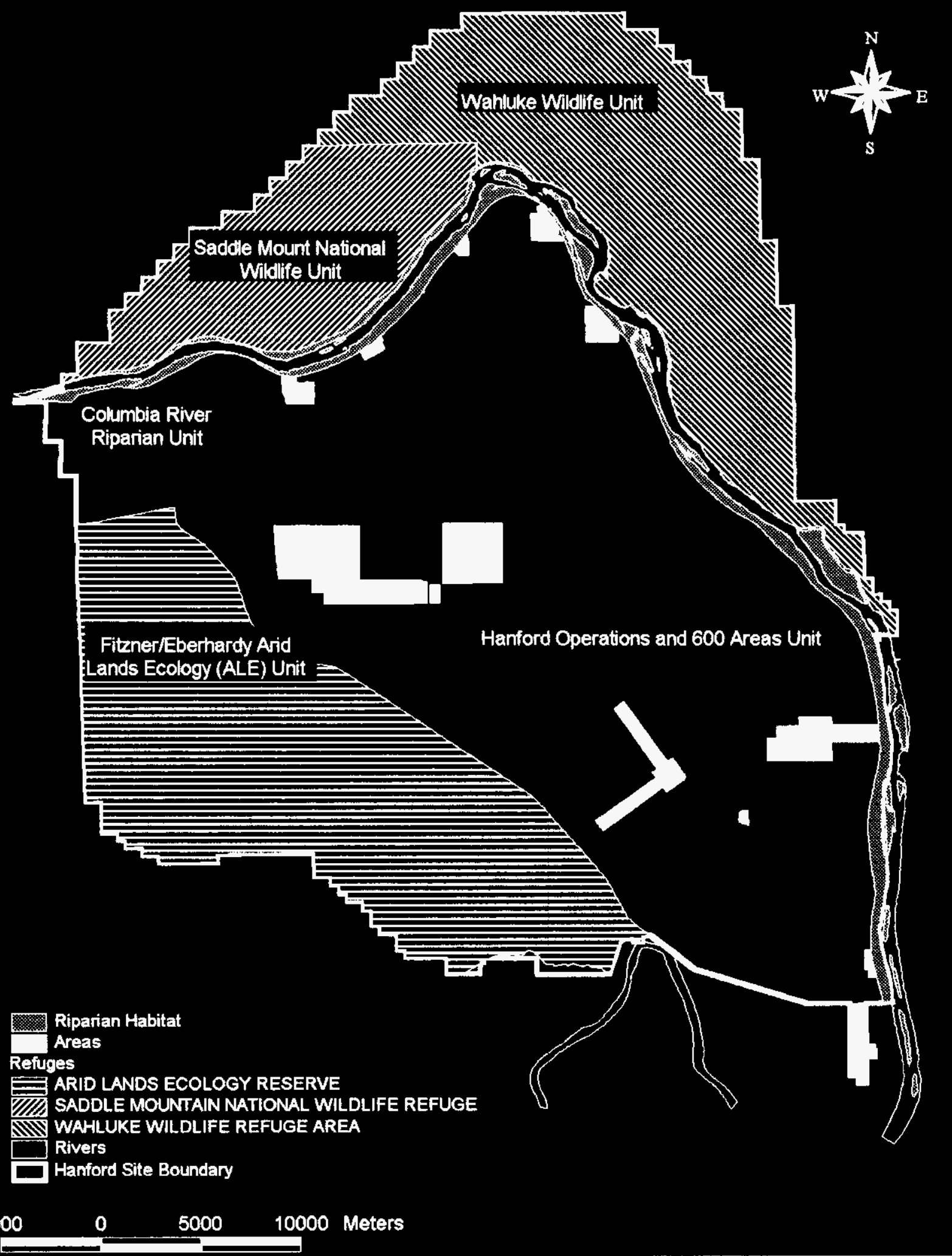


signed that coordinates its vegetation management activities among federal agencies. Major vegetation management considerations are as follows:

- Impacts on wildlife and habitat

- Coordination with U.S. Fish and Wildlife Service.

\section{Wahluke Wildlife Unit}

This unit consists of approximately $100 \mathrm{mi}^{2}$, managed for wildlife habitat and public recreation. Major features include the Columbia River riparian zone, permanent and ephemeral wetlands fed by the Columbia Basin Irrigation Project, the White Bluffs area, shrub steppe, and abandoned agricultural fields. The area is leased to the Washington State Department of Fish and Wildlife. That department is responsible for site management, including vegetation management. An MOU has been signed that coordinates vegetation management activities. Major vegetation management considerations are as follows:

- Impacts on wildlife and habitat

- Public access and recreation

- Coordination with Washington State Department of Fish and Wildlife and U.S. Bureau of Reclamation.

Hanford Operations and 600 Areas Unit

This unit is approximately $300 \mathrm{mi}^{2}$, bounded by the Columbia River on the north and east, Highway 240 on the west, and the city of Richland on the south. This is the Operations Area, and includes the 100,200,300, 400, and 3000 Areas and that portion of the 600 Area located within its boundaries. Major features are shrub steppe, abandoned agricultural fields, industrially disturbed land, and the Gable Mountain anticline, which is considered a sacred landform by native peoples who seasonally inhabited the area.

Current land use is the major influence on vegetation management in the Operations and 600 Areas. Vehicle transport of noxious weeds throughout, onto, and from the Hanford Site is a key concern. Major vegetation management considerations are as follows:

- Impacts on wildlife and habitat

- Public access and recreation

- Coordination with Washington State Department of Fish and Wildlife and U.S. Bureau of Reclamation. 
Columbia River Riparian Unit

The Columbia River and the riparian zone along the south and east banks will be managed separately from the rest of the Operations and 600 Areas. Riparian habitat often is susceptible to invading weed species that are completely different from those that invade the desert that makes up most of the rest of the Hanford Site. In addition, the control measures available for use on wetlands are severely restricted. Major vegetation management considerations are as follows:

- Impacts on wildlife and habitat

- Public access and recreation

- Coordination with the Washington State Department of Ecology. 


\section{AWARENESS EDUCATION AND TRAINING}

Awareness of what noxious weeds are, the regulations that require their control, and the problems they cause will help DOE, Westinghouse Hanford Company (WHC) management, and the general public understand why a long-term noxious weed management program is essential for the Hanford Site.

All personnel involved in the weed management program will be required to obtain the training, licenses, and certifications appropriate for their activities. Primary groups targeted by the awareness and education efforts will be IPM personnel involved with noxious weed management, biologists working on the Hanford Site, DOE and WHC management, Site personnel working in the field, other site personnel, and the public. Training objectives for each primary target group are significantly different. The basics and objectives of training for each group are described in the following paragraphs.

\section{NOXIOUS WEED MANAGEMENT PERSONNEL}

The overall objectives of the training for IPM personnel who manage noxious weeds are to maintain legal certification and qualifications to perform weed control and to develop knowledge and skills to perform their tasks efficiently and effectively. Generally, safety and operations training take place in onsite classes and specific technical certification and training take place offsite.

\section{BIOLOGISTS ON THE HANFORD SITE}

A number of organizations conduct biological surveys and monitoring on site. These groups include WHC, Pacific Northwest Laboratory, Bechtel Hanford Inc., and the Nature Conservancy. Biologists on site meet biannually with IPM personnel to share and update information. These meetings have the following main objectives:

- Update IPM database with new weed species or populations on site

- Alert site biologists to special concerns of the program (weeds threatening the site, populations that may be expanding, etc.).

\section{DOE AND WHC MANAGEMENT}

An excellent weed control program is of no value if it is implemented inconsistently or aborted prematurely. An annual meeting is held to review the program for DOE and WHC management to ensure continuity of funding for control activities. The meetings cover the following items. 
- Status and progress of program

- Review of laws and DOE orders mandating the program

- Review 10-year plan

- Present potential impacts of noxious weeds on regional economy and native ecosystems.

\section{SITE FIELD PERSONNEL}

Drillers, heavy equipment operators, health physics technicians, etc., who spend much of their time in the field are provided an overview of the program. This takes the form of a 30-minute training class accompanied by a pamphlet describing weed species. The objectives of the training sessions are to notify personnel of weed quarantines and how to respond to a quarantine area, provide basic information on weed transport and preventive measures, provide information for basic weed identification, and disseminate a phone number to report weed populations.

\section{GENERAL SITE PERSONNEL AND PUBLIC}

IPM participates with county weed boards and other weed managers in public education programs such as presentations to schools and booths at county fairs. Articles will be placed in internal WHC publications, such as the Hanford Reach, to make site personnel aware of the program and its benefits. 


\section{CONTROL MEASURES}

\section{PREVENTION AND EARLY DETECTION}

Prevention, early detection, and eradication of noxious weed species are the most practical means of weed management. An aggressive program has been developed at the Hanford Site to identify new weed populations early and to eradicate them before they become established.

\section{Prevention}

Prevention is best accomplished by ensuring that new weed species in the form of seed or vegetative reproductive plant parts are not introduced into an area. Common methods of accidental introduction include the following:

Wind- or water-borne seeds or plant parts. IPM works with surrounding counties to coordinate weed control.

- Movement of uncleaned equipment or machinery from a noxious-weedcontaminated area to an uncontaminated area. IPM establishes quarantine zones with special requirements for travel and transport of equipment. Appendix A describes the three levels of weed-area quarantine that may be used on the Hanford Site.

- Passenger vehicles transporting plant parts with viable seeds (caught on undercarriage, etc.). IPM may establish quarantine zones with special requirements for travel and transport of equipment (Appendix A).

Abandoned sites with bare soil. IPM stabilizes sites where soil has been disturbed and monitors the sites for at least 3 years. Plant cover is sometimes removed from the soil during construction, fire suppression, and other field activities, then the sites are abandoned. These sites, if not stabilized with a vegetative cover, are then invaded by weeds.

、 Gravel, fill, or top soil contaminated with noxious weed seed or reproductive plant parts. Active borrow pits for soil removal are regularly monitored by IPM for the presence of noxious weeds. Any noxious weeds identified are immediately destroyed.

- Reclamation materials, including mulches, seeds, and soil amendments. IPM monitors sites where reclamation materials have been used. Noxious weeds identified at these sites are treated as new weed populations and immediately destroyed. 
- Animals (domestic and wildlife) that have viable weed seed present in their digestive tracts or attached to their hair or wool. Most of the Hanford Site is closed to livestock grazing; however, areas open to grazing are monitored and weeds are managed.

\section{Early Detection}

Most areas of the Hanford Site are closed to public access. This eliminates a great deal of potential transport from traffic, recreational equipment, animals, etc. The most likely modes of transport for noxious weeds onto the Hanford Site are wind and water, vehicles along transportation routes, and construction activities that include potentially contaminated machinery and materials.

New weed populations are placed in a high-priority status as soon as they are identified. An integrated control program is designed and implemented as rapidly as possible, and continues until eradication is achieved. Transportation corridors are monitored twice yearly during the spring and fall blooming seasons. Road shoulders are routinely maintained to be kept free of weeds. Areas where vegetation has been removed and bare soil remains are stabilized and revegetated by IPM, and monitored until a healthy vegetative cover is established. Weed control is implemented on these areas as needed.

\section{INVENTORY AND MONITORING}

Inventory and monitoring are two of the most important tools of weed management. These tools are vital to planning, implementing, and subsequently evaluating the program.

Inventory

Inventory is a field tool used to establish a baseline condition. Inventory is performed when a new population is identified or when monitoring has not occurred so that a new baseline must be set. The noxious weed population inventory of the Hanford Site is scheduled to be completed by September 30, 1996. After the baseline inventory, new populations will be inventoried as they are identified. Information recorded in an inventory includes the following:

- Species. Recorded as Genus/species, common name, and accepted code (a four- or five-digit alpha-numeric code, uniquely identifying genus and species, standardized by the U. S. Department of Agriculture (USDA 1994).

- Location/Aerial Extent. Location and aerial extent may be hand plotted on U.S. Geological Survey 7.5-minute-series maps. However, the standard Hanford Site mapping system (currently Arcview II) will be used for 
permanent records. Where practical, maps will be recorded and updated using global positioning or a similar system.

- Density. Noxious weed density will be estimated visually as low, medium, or high. The density class criteria are:

- Low. Occasional plant per acre, less than 5-percent canopy cover

- Medium. Widely scattered plants, 5- to 25-percent canopy cover

- High. 25- to 100-percent canopy cover.

Species-specific criteria may modify the general density classifications.

Age Class. Average age class will be recorded for populations of large, woody, perennial plants. Plants will be visually identified as seedlings, young, or mature specimens. Populations will be assigned to a single age class if the preponderance of individuals fit one category, or mixed age if high percentages of individuals are present from each age class.

\section{Monitoring}

Following establishment of baseline conditions through initial inventory, populations are monitored periodically to update current baseline information. Monitoring is useful in identifying changing condition, and thereby evaluating the program's effectiveness. Information gained through periodic monitoring includes the following.

A Prioritization of Populations for Control Resources. A population that is rapidly increasing in area and density will be considered a higher priority for control than a population that is stable or expanding very slowly.

A Evaluation of Control Treatment Effectiveness. Monitoring a population before and after treatment provides a means of evaluating the treatment's effectiveness.

A Post-Control Monitoring. After control objectives have been met, the population is monitored for a time to identify early signs of population reemergence (seeds sprouting, dormant roots resprouting, open areas recolonized by wind-borne weed seeds).

- Early Detection of New Populations. Clean areas are monitored periodically to identify noxious weeds soon after establishment.

Several monitoring techniques are used. They range from relatively intensive data gathering such as reinventory to informal road surveys. Techniques include: 
- Reinventory. Recollection of part or all of the data originally in the baseline inventory including species, location, aerial extent, density, and age class. Information will update and establish a new baseline for future comparison.

- Photo-Trending. Periodic photos (usually annual) of the same location give visual documentation of changes in habitat condition and species composition. (See Appendix B for details.)

- Road Surveys. Quick and effective technique for identifying weeds along road shoulders. Particularly effective when conducted during blooming period.

- Coordination Among Biologists. Formal and informal information exchanges among the many experienced biologists who work on the Hanford Site.

\section{INTEGRATED WEED MANAGEMENT}

Integrated weed management is based on the following five management options. In every weed management situation, each option is evaluated separately and in combination with other options. The most effective treatment is then selected.

- No Action. If a weed population is unlikely to survive in the environment, or if management constraints or other considerations make control measures impractical, the no-action option may be the preferred management alternative.

- Cultural. Management practices in an area often contribute to weed infestation. Sometimes these practices can be changed. On the Hanford Site, quarantine zones are established that restrict vehicle access and activities. Quarantine requirements are outlined in Appendix A. Revegetation is another important cultural component of weed control. Establishing desirable species dramatically reduces the chances for weed infestation or reestablishment. These techniques are used most effectively in combination with other control techniques.

- Physical Controls. Some weeds are susceptible to burning or cultivation. When these practices do not conflict with management objectives for an area, and susceptible weeds are present, these physical controls are effective management techniques.

- Biological Controls. Biological control comes generally through competition from other plant species, pathogens, or predators. Competition can be enhanced by seeding competitive, non-weed species, or by manipulating soil 
chemistry and fertility. Pathogens and predators (seed-eating or root-boring insects, etc.) that may be introduced as part of the IPM control efforts are adapted specifically to a single plant species, or a group of species, and are determined not to be pests outside of the target weed species. Pathogens and predators will be used at the Hanford Site on dense populations that are not scheduled for other control efforts for at least 2 years.

- Chemical Controls. In most situations, herbicides are highly effective tools in controlling noxious weeds. In comparison with other control methods, chemical controls are often inexpensive. In practice, herbicides form the backbone of control for most weed management programs. Other control options are most effective when used to enhance or follow up chemical control.

An example of an integrated approach may be to quarantine an area by posting and fencing to prevent vehicle traffic (cultural). Insects destructive to the plant species may also be introduced (biological). After several years of insect infestation weakening the population, it could be burned (physical). Any regrowth may be sprayed with herbicide (chemical), and the area reseeded (cultural). In another situation, herbicide use may be very effective in selectively eliminating weeds, and other measures would be unnecessary. 
WHC-SD-EN-AP-187, Rev. 0

\section{EVALUATION AND REPORTING}

Three documents are prepared annually to report activities of the Noxious Weed Management program.

\section{Annual Program Status and Progress Report}

This is a supporting document prepared for distribution to WHC management, the customer, and others as appropriate. This document highlights work performed during the past fiscal year, and reports the status of control efforts sitewide and by population. The document will include:

- Summary of activities during report year.

- Statement of goals for the year.

Report of success in meeting goals for the year.

Status of 10-year planning goals and program goals.

Current maps, identifying weed species, density, aerial extent, and age class.

Trend comparison of most recent population maps to earlier maps (increase or decrease in area, population, etc.).

Evaluation of populations before and after treatment to measure the effectiveness of individual treatments.

Report on cooperative associations with neighboring land managers.

Address items in Appendix $\mathrm{C}$ as appropriate.

\section{Annual Schedule and Budget Projections}

This letter report to IPM management and funding organizations provides detailed funding projections and specific, detailed work schedules for the upcoming year. Early in the planning year, the report will be released once as a draft to the funding organization. It will be revised according to funding and current events, then will be finalized late in the planning year after funding is confirmed and current year results are evaluated. This report will include:

Program goals for the upcoming year 
WHC-SD-EN-AP-187, Rev. 0

- Specific (species/population) goals for the year

- Relate year's goals to 10-year and program goals

- Treatment methods

- Resource requirements and schedule (personnel, equipment, materials, budget)

- Anticipated contract requirements

- Goals and plans for public education and interagency cooperation

- Treatment and operations schedule by overall program, species, population, and acreage.

\section{Ten-Year Planning Projection}

The 10-year planning projection is an internal planning document identifying program objectives with the associated budget requirements for at least 10 years. The document will be reviewed and revised annually. Specific topics will include:

- Program goals, overall and arranged by year

- Projected resource requirements by year (personnel, equipment, materials, budget)

- Anticipated contract requirements by year

- Goals and plans for public education and interagency cooperation

- Projected species/population goals by year.

- Anticipated treatment activities for populations (Figure 1). 


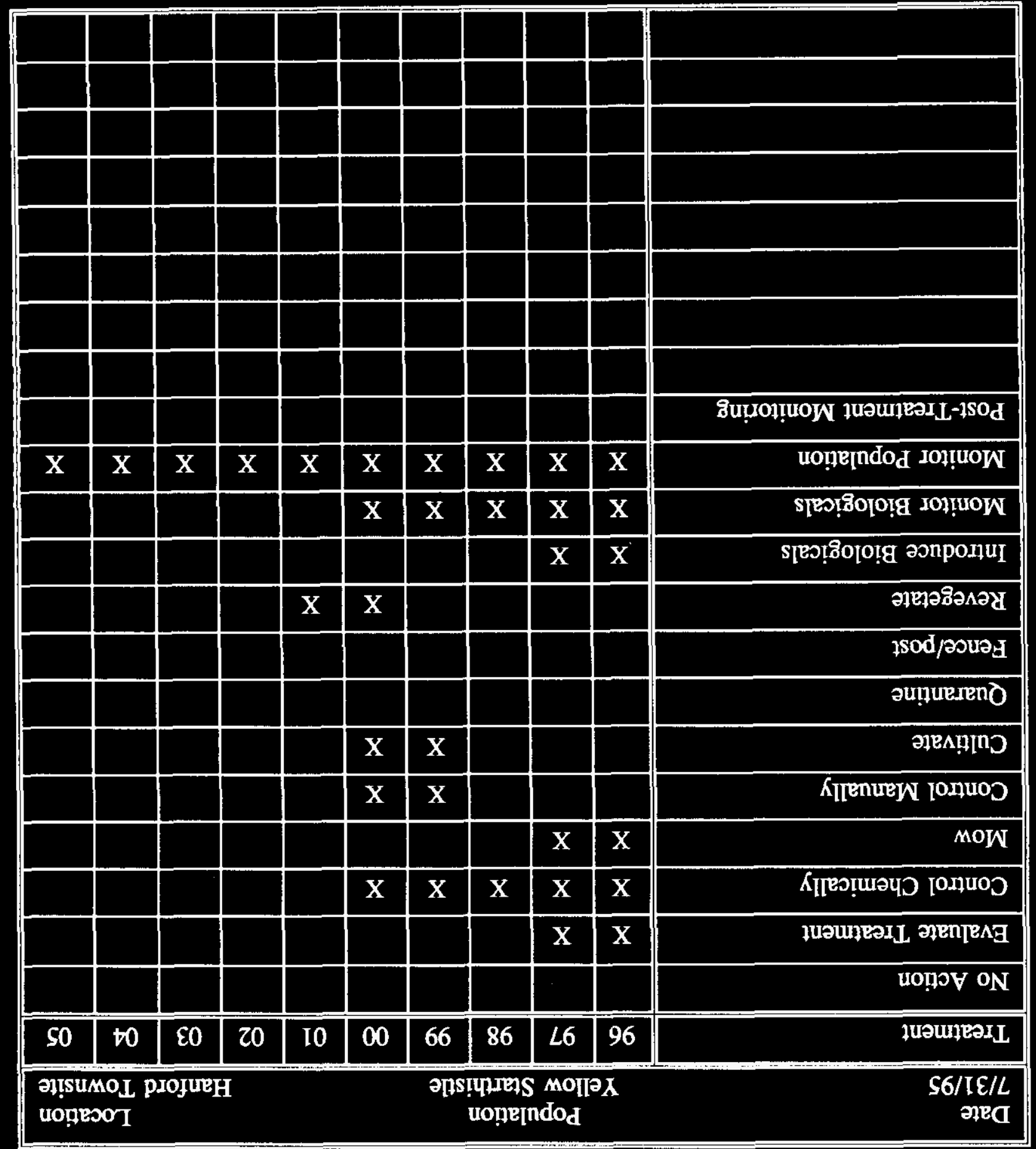

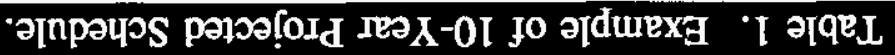


WHC-SD-EN-AP-187, Rev. 0

\section{REFERENCES}

Federal Noxious Weed Act of 1974, 7 USC 2801, et seq.

MOU, 1994, Memorandum of Understanding for the Establishment of a Federal Interagency Committee for the Management of Noxious and Exotic Weeds, U.S. Department of the Interior, U.S. Department of Agriculture, U.S. Department of Defense, U.S. Department of Transportation, and U.S. Department of Energy, Washington, D.C.

RCW 17.10, 1969, "Noxious Weeds--Control Boards," Revised Code of Washington, as amended.

USDA, 1994, Scientific and Common Plant Names, U.S. Department of Agriculture, Soil Conservation Service, Washington, D.C.

WAC 16-750, "State Noxious Weed List and Schedule of Monetary Penalties, "Washington Administrative Code, as amended. 
WHC-SD-EN-AP-187, Rev. 0

This page intentionally left blank. 
WHC-SD-EN-AP-187, Rev. 0

\section{APPENDIX A}

HANFORD SITE WEED QUARANTINE REQUIREMENTS 
WHC-SD-EN-AP-187, Rev. 0

This page intentionally left blank.

A-ii 


\section{APPENDIX A}

\section{HANFORD SITE WEED QUARANTINE REQUIREMENTS}

Seeds or other propagules of some weed species are particularly susceptible to transport by attaching to vehicles, equipment, humans, or animals. In some situations, it may be necessary to restrict access to an area during control of a weed species to prevent transport and establishment of weeds outside the control area. In these situations, the Integrated Pest Management (IPM) organization will establish weed quarantine areas.

Two levels of quarantine are implemented at the Hanford Site. Priority 1 Quarantine prohibits access to the area unless coordinated with IPM. Priority 2 Quarantine prohibits excavation and construction in an area unless coordinated with IPM.

Area quarantine has potential negative impact to site operations by making access more difficult for field activities. Therefore, quarantines are implemented carefully, and only in coordination with active, aggressive measures aimed at control of the weed population and lifting of the quarantine as rapidly as possible.

Establishment of a weed quarantine area will be at the discretion of the noxious weed control program manager. Factors considered in establishing quarantine areas include:

- Level of Local and Regional Infestation. Weed species that are confined to one or a few locations, and are not widespread in the Columbia Basin will be given high priority for quarantine. Weeds that are widespread both locally and regionally will have low priority for quarantine.

- Invasiveness of Weed Species. Species that are expected to aggressively expand from satellite populations will be given higher priority than species with slower establishment and expansion potential.

- Potential for Economic Impact. Species that are expected to have a major impact on agriculture, aggressively invade recreational areas (e.g., yellow starthistle), or have other major economic impacts will be given higher priority.

- Potential for Environmental Impact. Species that tend to form monocultures and displace native habitats (e.g., purple loosestrife) will be given higher priority.

- Probability of Seeds Being Transported by Vehicles or Equipment - Species with seeds that are long-lived, and persistent on plants that may be caught on vehicles or equipment, or attached to clothing will be given priority over species with seeds that are fragile and shatter quickly from the plant. 
Priority 1 Quarantine

A Priority 1 quarantine area will be fenced around the perimeter or at least across all reasonable access points. A warning/information sign will be posted at each access point providing the following information:

- Access restriction

- Species of concern

- Brief summary of reason for quarantine, and control measures

- Expected duration of quarantine

- IPM contact and phone number for information and access

IPM will work with personnel requiring access to the quarantine sites. IPM personnel may accompany others into the quarantine areas and assist in avoiding transport of weed seeds and propagules. Persons requiring frequent access may be trained in methods for avoiding weed transport.

Priority 2 Quarantine

A Priority 2 quarantine area will have warning/information signs posted at the vehicle access points. The signs will contain the same information as Priority 1 quarantine signs, and will include brief tips on avoiding weed transport. Access to the area will not be prohibited, but specific sites of infestation may be fenced. 
WHC-SD-EN-AP-187, Rev. 0

APPENDIX B

PHOTO-TRENDING PROCEDURES

B-i 
WHC-SD-EN-AP-187, Rev. 0

This page intentionally left blank.

B-ii 
WHC-SD-EN-AP-187, Rev. 0

\section{APPENDIX B}

\section{PHOTO-TRENDING PROCEDURES}

\section{PHOTO-TRENDING PHILOSOPHY AND CRITERIA}

Photo-trending consists of documenting changes in an area over time by taking a series of photographs under (as nearly as possible) identical conditions. In this case, photo-trending will document the status of specific noxious weed populations. Photographs will be taken on an annual basis whenever practical, and will be used to document population dynamics. Photo-trending ideally should begin before control efforts.

\section{Population Selection}

Major weed populations should be photographed. Criteria helpful in evaluating which populations to photograph include:

- Aerial Extent of Population. Larger populations generally require more substantial control efforts. An expanded or long-term control effort should be given priority for photo-trending.

- Density of Infestation. Established weed populations are well suited to photo-documentation they have an abundance of plants. Weed infestations with scattered individuals may not be apparent on a photograph.

- Invasiveness of Species. A species or population that has a high probability of expanding should receive high priority for photo-trending.

- Sensitivity of Area. Photo-trending of sensitive areas will help document progress or, if necessary, the need for additional efforts in these areas.

- Expected Effort to Eradicate. If a population can be eradicated within a year or two, photo-trending may not be appropriate. Populations requiring longterm efforts or those with maintenance as the control objective may be appropriate for photo-trending.

- Impact of Population Relative to Other Populations of Same Species. A weed species may have several populations on the Hanford Site. A few representative or high-impact populations should be selected to document the status of the species. 
WHC-SD-EN-AP-187, Rev. 0

Photopoint Set-Up

- Select format and lens for consistency among photos. A 35-mm camera format and 28-mm lens are traditional.

- Select film for consistency among photos. Use all black and white negatives, all color negatives, all color slide, or all black and white slides.

- Select time of shoot for consistency. Use the same calendar date, or phenological stage (full bloom, spring emergence, fall seed set, etc.) to ensure an accurate comparison between years.

- Select shoot location and direction for best display of population.

- Select shoot location considering possible future disturbance. Try to select locations that will remain the same throughout the photo-trending period.

- Set permanent post at camera location and height.

- Record compass azimuth of photograph using post as reference point.

- Attach a sign containing the following legend to the reference post:

PERMANENT PHOTO REFERENCE POINT

DO NOT DISTURB

FOR INFORMATION, CONTACT

NAME PHONE NUMBER

- Document reference point with the following information:

- $\quad$ species of concern

- $\quad$ survey location

- compass azimuth of photograph

- $\quad$ height of camera above ground.

- Drive a 5/8-in. x 15-in. reinforcing rod to several inches below ground surface. The rod can easily be located with a metal detector and can be used to relocate precise photo point in case of accidental removal or destruction of reference posts.

- Photograph reference photo. A copy of this photo will be carried into the field each year at the time of population photograph. Using the same camera format and lens size, each year's photo will be framed as precisely as possible to duplicate the reference photo. 
WHC-SD-EN-AP-187, Rev. 0

Yearly Photograph

- At the predetermined calendar period or plant phenological stage, select a day with suitable weather conditions and a time of day with light that is appropriate for the photograph.

A Use the predetermined camera format and lens size.

A Take the photograph from the predetermined location, angle, and elevation (distance from ground).

- Frame the scene so that the photograph will duplicate the reference photograph.

A In the lower corner of the photograph, show a sign with the following information:

Population Identifier

Species

Date

- Prepare a narrative describing the site conditions and providing appropriate information, such as recent control activities or other effects on the population. The narrative will be kept as part of the permanent record. 
WHC-SD-EN-AP-187, Rev. 0

This page intentionally left blank. 
WHC-SD-EN-AP-187, Rev. 0

\section{APPENDIX C}

PROGRAM STATUS AND PROGRESS REPORT QUESTIONS 
WHC-SD-EN-AP-187, Rev. 0

This page intentionally left blank.

C-ii 
WHC-SD-EN-AP-187, Rev. 0

\section{APPENDIX C \\ PROGRAM STATUS AND PROGRESS REPORT QUESTIONS}

The following questions are used as appropriate as topics in preparation of the program status and progress reports. (From Guidelines for Coordinated Management of Noxious Weeds in the Greater Yellowstone Area)

Were weed populations adequately suppressed?

Were planned procedures used? If not, what was different?

Was cost of suppression less than, greater than, or equal to expected?

What damage was produced through control efforts? How much was acceptable?

Were biological controls affected by control efforts?

Was desirable vegetation harmed/benefitted by control activities?

Were there other side effects of control activities?

How effective were treatments?

What will be done in the future to increase effectiveness?

What are the newest techniques, technology in weed control?

What new laws, regulations, or policies affect weed control?

Was training adequate?

NPS, USDA, USDI, Guidelines for Coordinated Management of Noxious Weeds in the Greater Yellowstone Area, National Park Service, U.S. Department of Agriculture, U.S. Department of the Interior, Washington, D.C. 
WHC-SD-EN-AP-187, Rev. 0

This page intentionally left blank.

C-2 
WHC-SD-EN-AP-187, Rev. 0

\section{DISTRIBUTION}

\section{Number of Copies}

\section{OFFSITE}

5

U.S. Department of Energy-

Headquarters

1000 Independence Ave.

Washington, D.C. 20585

H. Beckert

TH-232

ONSITE

3

U.S. Department of Energy, Richland Operations Office

N. G. Thomas

A2-45

45

Westinghouse Hanford Company

M. R. Adams

H6-30

R. F. Giddings

S3-24

A. R. Johnson

H6-20

C. L. Looney (2)

S3-24

M. B. Malady (30)

S3-24

D. E. May

S3-24

R. A. Meznarich

H6-30

R. M. Mitchell

H6-30

J. M. Rodriguez

S3-24

R. C. Roos (2)

H6-30

R. F. Thornton

S3-24

Central Files

A4-18 


\section{WHC-SD-EN-AP-187, Rev. 0}

This page intentionally left blank. 